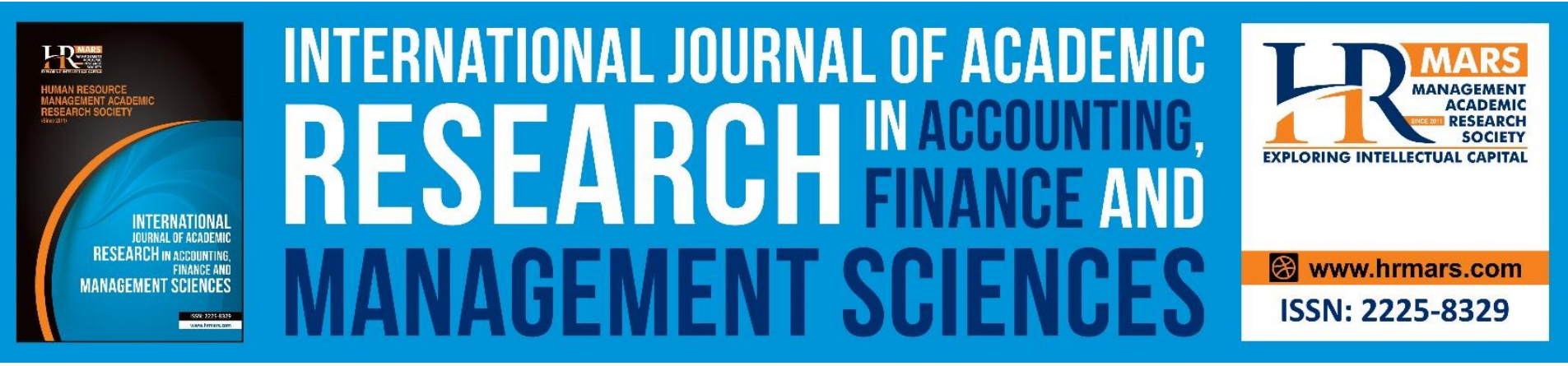

\title{
How Does Corporate Social Responsibility Affects Brand Positioning and Brand Loyalty: An Empirical Analysis of Selected Fmcg Companies
}

Atalla Fahed Al-Serhan

To Link this Article: http://dx.doi.org/10.6007/IJARAFMS/v11-i1/8877

DOI:10.6007/IJARAFMS /v11-i1/8877

Received: 20 January 2021, Revised: 21 February 2021, Accepted: 01 March 2021

Published Online: 19 March 2021

In-Text Citation: (Al-Serhan, 2021)

To Cite this Article: Al-Serhan, A. F. (2021). How Does Corporate Social Responsibility Affects Brand Positioning and Brand Loyalty: An Empirical Analysis of Selected Fmcg Companies. International Journal of Academic Research in Accounting Finance and Management Sciences, 11(1), 99-119.

\section{Copyright: (c) 2021 The Author(s)}

Published by Human Resource Management Academic Research Society (www.hrmars.com)

This article is published under the Creative Commons Attribution (CC BY 4.0) license. Anyone may reproduce, distribute, translate and create derivative works of this article (for both commercial and non-commercial purposes), subject to full attribution to the original publication and authors. The full terms of this license may be seen

at: http://creativecommons.org/licences/by/4.0/legalcode

Vol. 11, No. 1, 2021, Pg. 99 - 119

http://hrmars.com/index.php/pages/detail/IJARAFMS

JOURNAL HOMEPAGE

Full Terms \& Conditions of access and use can be found at http://hrmars.com/index.php/pages/detail/publication-ethics 


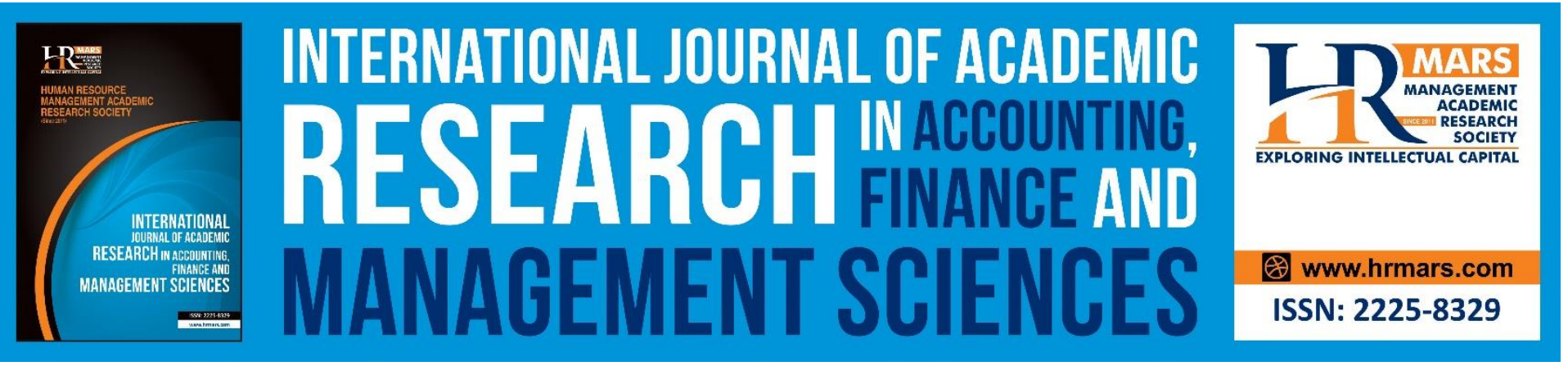

\title{
How Does Corporate Social Responsibility Affects Brand Positioning and Brand Loyalty: An Empirical Analysis of Selected Fmcg Companies
}

\author{
Dr. Atalla Fahed Al-Serhan \\ Assistant Professor, Department of Business Administration, Al Albayt University, Mafraq, Jordan
}

\begin{abstract}
Brand Positioning refers to designing a brand offer while aiming that it succeeds to occupy a distinctive place in the minds of the target customers. It has become the key to survival these days. All the purchase decisions are directly or indirectly linked with brand positioning. A firm that succeeds to distinguish itself by the fair use of brand positioning also succeeds to attract and retain customers. All the firms tried to design strategies for better positioning, but an evident change in consumer attitude in the past decade indicates consumers' developing preference towards companies who, in addition, care for the society and environment as well. The businesses houses started realizing that they would have to take care of society and to minimize the social costs. This has resulted into the concept of Corporate Social Responsibility (CSR). It states that firms must integrate social and environmental concerns in their business activities voluntarily. This study has been conducted to investigate the impact of CSR on brand positioning and brand loyalty. Popular FMCGs like Unilever, P\&G, Nestle, Coca Cola, Pepsico have been selected in the study. The sample size is 255 respondents selected after the application of judgemental sampling. The findings highlighted strong support for the hypothesized relationships. The study found significant impact of CSR in brand positioning and brand loyalty.
\end{abstract}

Keywords: CSR, Brand Positioning, Brand Loyalty, Regression, FMCG, Jordan.

\section{Introduction}

Corporate Social Responsibility is the commitment that corporates owe to society that should be reimbursed. It is a method of expressing gratitude towards the environment wherein they work (Arevalo and Aravind, 2011). It is a method of showing sense of belonging to the general public. CSR is a path for the companies to connect with their host communities by emphatically affecting their current surroundings (Park, Kim, and Kwon, 2017). It is a social commitment by the firms with their customers, employees, suppliers, societies, and environment because they earn profits by using the resources given by the environment (Peloza \& Shang, 2011). It has become the common phenomenon in the present world because of its notable impact on society. Fortune companies 
across the world spend billions of dollars in fulfilling CSR activities to enhance their reputation and to maintain strong customer relationship management (Dapi and Phiri, 2015).

A firm is said to attain CSR when it contributes towards sustainable development by taking into consideration the concerns of employees, shareholders, investors, government, and the local community in particular and society in general. CSR activities focusing on sustainability issues get higher sales, higher customer satisfaction, and strong brand image, employees' loyalty (Russo and Perrini 2010). CSR states that firms integrate social and environmental concerns in their business activities voluntarily (Wu \& Wang, 2014). A company takes steps to ensure that there shall be minimum negative external costs associated with the way the business operations. Not exclusively can CSR models bring about an ascent in the business and income, but they additionally advance change and progress all over the world, which usually includes assisting individuals with few or no assets (Sen, Bhattacharya, and Korschun, 2006). There is no exact definition for CSR because different businesses used different approaches in handling it. The current study used the most popular and most cited model propounded by Carroll, 1991 to take the components of CSR (Figure 1). This study has also break down CSR into four dimensions namely economic, legal, ethical, and philanthropic components. Thereafter, three or four statements have been drafted to measure each component by the researcher. The detailed discussion of all dimensions of CSR has been in the research model.

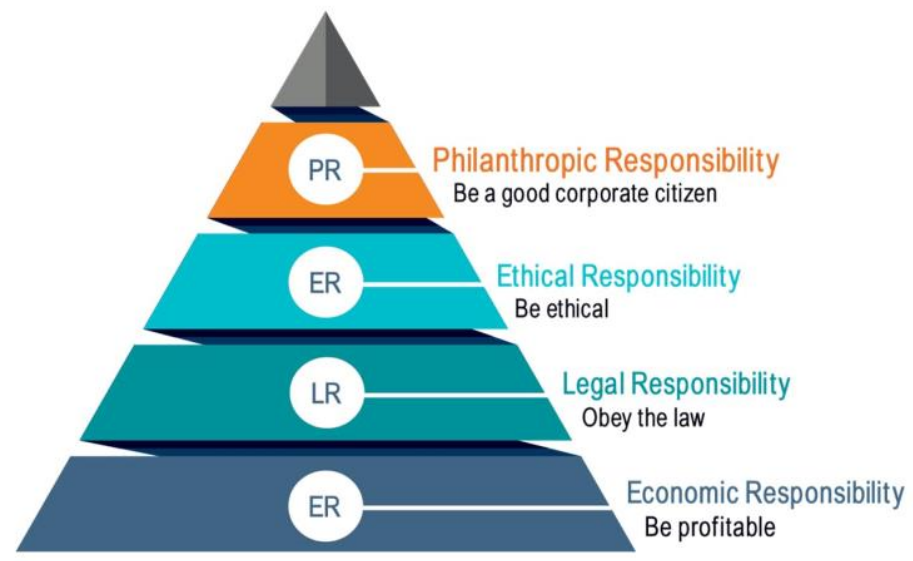

Figure 1: The Pyramid of CSR model by Carroll, 1991

\section{CSR and Brand Positioning}

Brand positioning describes how a brand is different from its competitors and where, or how, it sits in customers' minds (Abushttal and Al Serhan, 2020). According to Kotler, brand positioning is the process of designing the company's offering and image to occupy a distinguish place in the mind of the target market. It is the eccentric space a brand occupies in the customers' minds. It is a deciding factor which determines the sales of a product. The aim of brand positioning is to make a product unique by adding emotions, traits, feelings, which make it different from the competition. It is essential because all purchase decisions are based on brand positioning (Ying, 2005). It is not just about getting any particular product but also accessing a brand's reputation, prestige, goodwill and quality. For example, McDonald is a leader in the fast food industry and known for its friendly service that make it different from other fast food restaurants. Similarly, Apple dominates the technology 
market by positioning its brand which offers dignity and luxury. Another example is Amazon which positioned itself on the basis of low price and quick delivery.

In the past decade, business houses have changed their positioning strategies by incorporating CSR as one the important tool vis-a-vis quality, features. There is a surge in the number of companies worldwide which start promoting their business through CSR strategies because the customers, the public and the investors expect them to act sustainable as responsible. Many empirical studies highlighted a significant impact of CSR activities on brand positioning. Raza Naqvi, et al. in the year 2013 revealed that majority of the consumers preferred to Unilever compared to other brands because it had launched Unilever Foundation in 2012 which helped one billion people in improving their health and living standard.

\section{CSR and Brand Loyalty}

Brand loyalty is the tendency of consumers to continuously purchase one brand's products over another. A firm is said to achieve brand loyalty when a customer continues to purchase from one company, not because it's the only option, but because he trusts the company (Maldonado-Guzman et al.,2017). There is a direct correlation between brand loyalty and brand positioning. A customer does not become loyal to a firm in a short duration. He becomes loyal when he examined the company from different aspects like pricing, quality, availability of products, attributes, and CSR. A worldwide change in consumers' attitude has been recorded (Oberseder, Schlegelmilch, and Murphy, 2013). Today, a customer thinks that he directly cannot do anything for the society because of financial problems and time constraints. So, consumer prefers to those companies that are contributing either small or big towards environment and society. While making a purchase decision, he has a question in his mind that if the prices and other things of a product are equal, why not the money should goes to the firm which bothers to poor in the country. Many empirical studies have found that the firms obliging their CSR activities are able in getting brand loyalty. The research conducted by Bediako (2017) revealed that customers were very much aware of the CSR activities CSR has an effect on their loyalty willing to purchase trips from the company. 


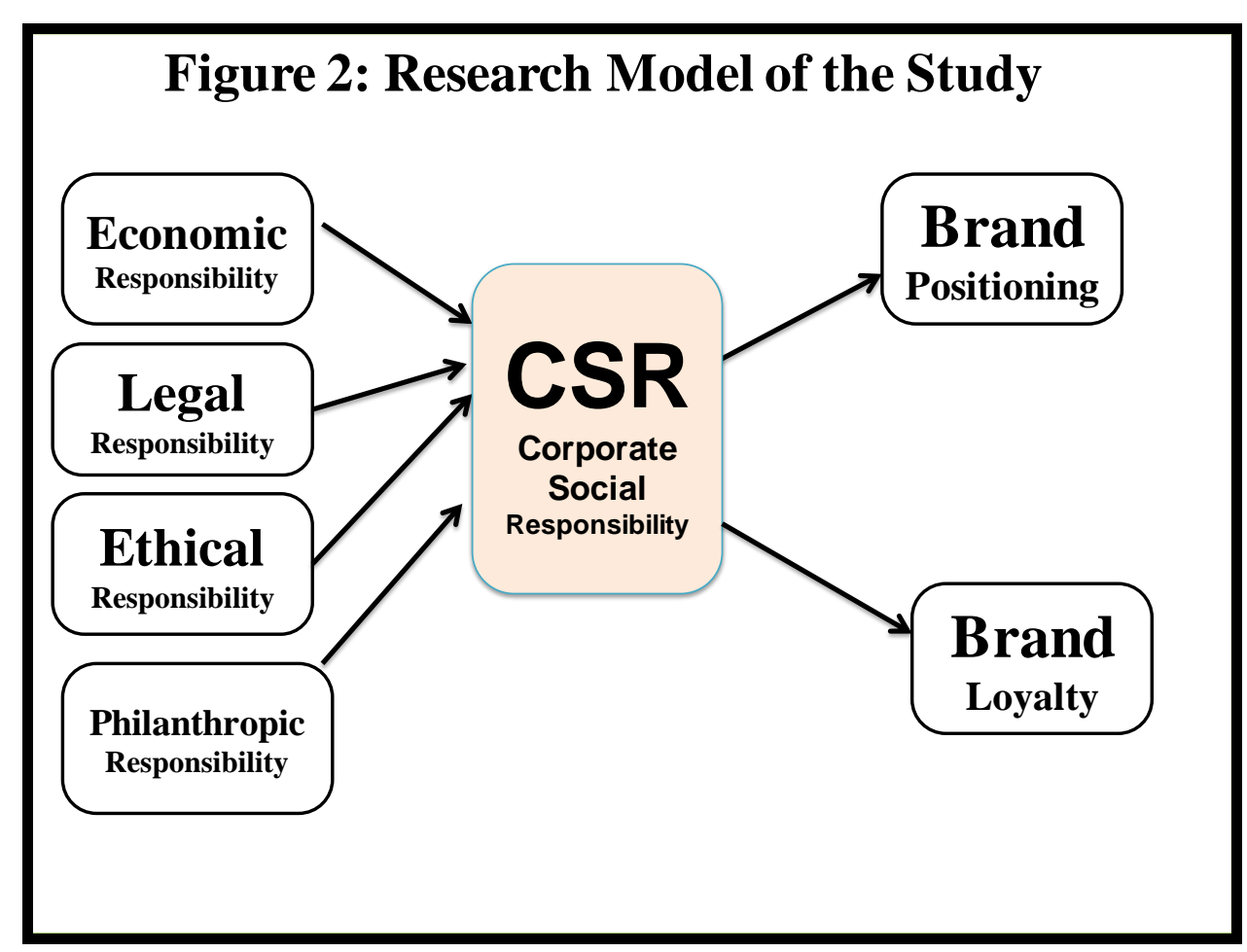

Source: Researcher's Own Compilation

\section{Research Model}

Figure 2 exhibits the research model of the current research. CSR has been used as the independent variable whereas brand positioning and brand loyalty have been used as dependent variables. There is no exact definition for CSR because different businesses have different approaches in handling it. Therefore, components of CSR are different from studies to studies. The present study used four components of CSR which were also used in many previous empirical studies. These include economic responsibilities, legal responsibilities, ethical responsibilities, and philanthropic responsibilities. All these are discussed below.

The first component of CSR in this research is economic responsibilities. It asks the questions whether the company tries to obtain maximum profits from its CSR activities; whether the firm generates employment opportunities and do sustainable development; whether the company actively sponsors or finance social events. The second component of CSR is the legal responsibilities. This component asks the questions like whether the company always pays its taxes regularly; whether the company abides by the norms for legitimate functioning of CSR activities; whether the company is trustworthy on account of providing full and accurate information to consumers; whether the company respects consumer rights and avoids unfair competition; whether the company respects the norms defined in the law when carrying out CSR activities.

The third component of CSR is the ethical responsibilities. It asks the questions whether the company behaves ethically and honestly with its customers; whether the managerial decisions related with the employees are usually fair and without any discrimination; whether the company policies are flexible and provide work-life balance to employees. Furthermore, the fourth component of CSR is philanthropic responsibilities. It asks the questions like whether the company reserves a portion of its 
INTERNATIONAL JOURNAL OF ACADEMIC RESEARCH IN ACCOUNTING, FINANCE AND MANAGEMENT SCIENCES

Vol. 11, No. 1, 2021, E-ISSN: 2225-8329 ๔ 2021 HRMARS

profits for donations and social work; whether the company considers itself responsible to benefit the community in its operating areas as a reimbursement.

The dependent variable brand loyalty asks the questions like whether the respondent is loyal to the company, whether the respondent preferred to the company even if another brand available in the market. The second dependent variable brand positioning asks the questions whether the respondents' promptly remember the symbol or logo of the brand, whether they like the quality of the brand etc.

\section{Literature Review}

Galbreath (2010) Data was collected through a survey of CEOs. CFA was run while regression analysis was used to test the hypotheses. The findings suggested that firms obliging CSR benefited with reduced employee turnover, higher degree of customer satisfaction and overall strong firm's reputation. Naqvi, et al. (2013) examined the relationship between CSR and four dimensions of brand image. It was found that majority of the consumers preferred to Unilever compared to other brands because it had launched Unilever Foundation in 2012 which helped one billion people in improving their health and living standard. The authors revealed that CSR should be implemented by all firms because it creates positive impact on the thinking of its consumers which brings a positive picture of the company. Gudjonsdottir and Jusubova (2015) examined the impact of CSR on brand image with the application of correlation test and a multiple regression. The sample size was 73 respondents. A strong and positive relationship between the brand image and CSR was recorded. CSR has become a strategic marketing tool to improve the brand image and suggested that CSR should be used by the companies as competitive advantage to overcome competition. Nagalatha (2015) examined the perception of managers on CSR in India. The companies with the turnover of Rs.100 crores and more were selected in the study. The period of the study was September, 2013 to March, 2014. All the independent variables like ethical ideology of managers, perception of managers on CSR, fund allocation, nature and type of business and ownership have significant influence over CSR activities. Furthermore, the cost of developing and implementing CSR initiatives are expensive and so decision makers should create a separate budget to finance the programe and to ensure their success and sustainability. CSR report must be added in the annual report and the money spent on CSR activities must be highlighted which will strengthen the corporate accountability and transparency. The research further revealed that India is the country where CSR is mandatory and Indian corporations are required to spend $2 \%$ of their net profit in CSR activities. Maximum numbers of activities were conducted by public companies than private and MNC companies. Lin (2016) tried to examine the impact of CSR on brand size, brand segment, brand identity with the help of field surveys in the restaurants of USA. The sample size was 348 usable responses. The results indicated that brand size, brand segment, and brand identity are positively related with CSR. Bediako (2017) analyzed the impact of CSR on the loyalty of StanBed Tours customers. The sample size of the study was 100 respondents and their responses were taken through web survey. CSR was measured across economic component, legal component, ethical component, and philanthropic component. The findings revealed that customers were very much aware of the CSR activities CSR has an effect on their loyalty willing to purchase trips from the company because of their engagement in CSR. Besides, the author recommended that CSR activities must be communicated via an annual report. Lu et al (2020) examined the impact of CSR in improving 
the competitiveness of the firm. Brand loyalty and brand image were taken as the components to measure the competitiveness of a firm. Structured questionnaires were used to collect data from 364 consumers from August 2018 to December 2018. The researchers applied Structural equation modeling (SEM) and CFA for analysis. The findings highlighted that a significant and positive impact on brand loyalty as well as on brand image due to the CSR activities conducted by the selected firms.

\section{Research Gap}

After a comprehensive literature review, it has been found that countless studies conducted on the impact of CSR on brand equity. Some studies examined the impact of CSR on brand positioning. Besides, researches are also done which investigated the impact of CSR on brand loyalty. But, a few empirical studies are conducted with respect to Jordan. Therefore, this study is identical because of two reasons. Firstly, it examines the impact of CSR on brand positioning and brand loyalty. Secondly, this study has worked on FMCG companies in Jordan.

\section{Research Questions}

1. What is the impact of CSR on brand positioning in selected FMCGs of Jordan?

2. What is the impact of CSR on brand loyalty in selected FMCGs of Jordan?

\section{Objectives of the Study}

1. To examine the impact of corporate social responsibilities (CSR) on brand positioning (BP) in selected FMCGs of Jordan.

2. To investigate the impact of corporate social responsibilities (CSR) on brand loyalty (BL) in selected FMCGs of Jordan.

3. To give a contextual background of CSR in brief and an overview of selected FMCGs.

\section{Hypotheses of the Study}

According to first objective, the hypotheses are:

$\mathrm{H}_{01}$ : There is no significant impact of CSR on brand positioning in selected FMCGs of Jordan.

$H_{01.1}$ : There is no significant impact of economic responsibilities on brand positioning.

$\mathrm{H}_{01.2}$ : There is no significant impact of legal responsibilities on brand positioning.

$\mathrm{H}_{01.3}$ : There is no significant impact of ethical responsibilities on brand positioning.

$\mathrm{H}_{01.4}$ : There is no significant impact of philanthropic responsibilities on brand positioning.

According to second objective, the hypotheses are:

$\mathrm{H}_{02}$ : There is no significant impact of CSR on brand loyalty in selected FMCGs of Jordan.

$\mathrm{H}_{02.1}$ : There is no significant impact of economic responsibilities on brand loyalty.

$\mathrm{H}_{02.2}$ : There is no significant impact of legal responsibilities on brand loyalty.

$\mathrm{H}_{02.3}$ : There is no significant impact of ethical responsibilities on brand loyalty.

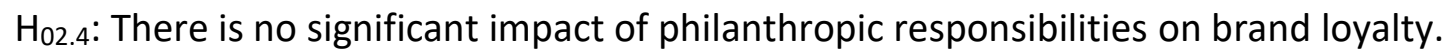

\section{Primary Data and Secondary Data}

Both primary and secondary data have been collected for this study. A judgemental sampling was adopted for the selection of 255 respondents from selected FMCGs in Jordan. Data was collected 
INTERNATIONAL JOURNAL OF ACADEMIC RESEARCH IN ACCOUNTING, FINANCE AND MANAGEMENT SCIENCES

Vol. 11, No. 1, 2021, E-ISSN: 2225-8329 @ 2021 HRMARS

through a structured questionnaire designed on Likert five point scale. 400 questionnaires were distributed during the second half of 2019. The researcher gathered only 300 questionnaires. Besides, the unfilled 45 questionnaires were rejected out of 300 received questionnaires. In this way, a total of 255 questionnaires were used for analysis in this study. Moreover, the secondary data was collected from books, journals, research articles and from conference proceedings.

Table 1: Questionnaires distributed and accepted

\begin{tabular}{|c|c|c|c|c|}
\hline \multicolumn{4}{|c|}{ Questionnaires } & \multirow{2}{*}{ Period of Survey } \\
\cline { 1 - 4 } Distributed & Returned & Rejected & Accepted & \\
\hline 400 & 300 & 45 & $\mathbf{2 5 5}$ [Sample Size] & July,2019 to December,2019 \\
\hline
\end{tabular}

Source: Primary Data

\section{Period of the Study}

A pilot study was conducted on 50 respondents in the month of May, 2019. Based on the results of pilot study, the questionnaire was modified and field survey was conducted for the main study during July, 2019 to December, 2019.

\section{Selected FMCG Companies}

Major FMCG companies in Jordan namely Unilever, Proctor and Gamble, Nestle, Cadbury, Coca Cola, Pepsico, Johnson \& Johnson, Reckitt Benckiser were selected in the study for analysis. The structured questionnaire has been sent to the consumers of these companies.

\section{Statistical tools used in Data Analysis}

The following techniques were used with the help of SPSS version 18 to analyze the data.

a) Cronbach alpha has been used to test reliability and accuracy of the data.

b) Simple regression analysis has been used to examine the impact of independent variable on dependent variable.

\section{Reliability Testing}

Before hypotheses testing, reliability of all components as well as all statements of questionnaire was examined with the application of cronbach alpha. Table 2 highlights the reliability of all statements under study. The alpha values of all statements were ranging from 0.7 to 0.9 and the overall reliability has been 0.825 . Hence, it can be said that the data has been reliable for testing hypotheses. 
Table 2: Reliability Testing

\begin{tabular}{|c|c|c|}
\hline \multicolumn{2}{|c|}{ Economic Responsibilities } & \multirow{2}{*}{$\begin{array}{l}\text { Cronbach } \\
\text { alpha }\end{array}$} \\
\hline 1 & $\begin{array}{l}\text { This company also aims to maximise profits obtained from its CSR } \\
\text { activities. }\end{array}$ & \\
\hline 2 & This company creates employment opportunities & 0.846 \\
\hline 3 & The company does sustainable development. & 0.734 \\
\hline \multicolumn{3}{|c|}{ Legal Responsibilities } \\
\hline 5 & The company always pays its taxes regularly without any delay. & 0.902 \\
\hline 6 & $\begin{array}{l}\text { This company abides by the norms for legitimate functioning of CSR } \\
\text { activities. }\end{array}$ & 0.814 \\
\hline 7 & $\begin{array}{l}\text { I find this company trustworthy as it provides fully accurate } \\
\text { information about its products to the customers. }\end{array}$ & 0.799 \\
\hline \multicolumn{2}{|c|}{ Ethical Responsibilities } & \\
\hline 8 & $\begin{array}{l}\text { The managerial decisions related with the employees are usually } \\
\text { fair. }\end{array}$ & 0.843 \\
\hline 9 & This company behaves ethically and honestly with its customers. & 0.794 \\
\hline 10 & This company avoids unfair competition. & 0.822 \\
\hline 11 & $\begin{array}{l}\text { The company policies are flexible and provide room for maintain } \\
\text { work-life balance to employees. }\end{array}$ & 0.807 \\
\hline \multicolumn{2}{|c|}{ Philanthropic Responsibilities } & \\
\hline 13 & $\begin{array}{l}\text { This company reserves a portion of its profits for donations and } \\
\text { social work. }\end{array}$ & 0.911 \\
\hline 14 & $\begin{array}{l}\text { This company integrates charitable contribution into it business } \\
\text { activities }\end{array}$ & 0.862 \\
\hline 15 & $\begin{array}{l}\text { This company considers itself responsible to benefit the community } \\
\text { in its operating areas as a reimbursement. }\end{array}$ & 0.833 \\
\hline \multicolumn{2}{|c|}{ Brand Positioning } & \\
\hline 16 & The likely quality of this brand is extremely high. & 0.822 \\
\hline 17 & $\begin{array}{l}\text { The high quality products of the company help me in remembering } \\
\text { it. }\end{array}$ & \\
\hline 18 & I do not feel any difficulty in thinking and picturise this company. & 0.851 \\
\hline \multicolumn{2}{|c|}{ Brand Loyalty } & \\
\hline 19 & $\begin{array}{l}\text { I will restain from buying any other products if this brand's products } \\
\text { are available at the store. }\end{array}$ & 0.809 \\
\hline 20 & $\begin{array}{l}\text { I would prefer to buy this brand even if another brand has same } \\
\text { feature. }\end{array}$ & 0.833 \\
\hline \multirow[t]{2}{*}{21} & I will remain faithful to this company. & 0.844 \\
\hline & Overall Reliability & 0.825 \\
\hline
\end{tabular}

Source: Output of SPSS_18 


\section{Hypotheses Testing}

The study has two main hypotheses and four sub hypotheses were developed under each hypothesis. The first hypothesis examines the impact of CSR on brand positioning whereas second hypothesis examines the impact of CSR on brand loyalty. All these were tested with the application of simple linear regression.

$H_{01.1}$ : There is no significant impact of economic responsibilities (ER) on brand positioning (BP).

$H_{a 1.1}$ : There is a significant impact of economic responsibilities (ER) on brand positioning (BP).

Table 3: Regression [Economic responsibilities \& Brand positioning]

\begin{tabular}{|c|c|c|c|c|c|c|c|c|c|}
\hline \multicolumn{9}{|c|}{ Model-1 } & \multicolumn{5}{|c|}{ Change Statistics } \\
\hline $\mathbf{R}$ & $\mathbf{R}^{\mathbf{2}}$ & $\begin{array}{c}\text { Adjuste } \\
\mathbf{d ~ \mathbf { R } ^ { 2 }}\end{array}$ & $\begin{array}{c}\text { Standard } \\
\text { Error }\end{array}$ & $\begin{array}{c}\text { Durbin } \\
\text { Watson }\end{array}$ & $\begin{array}{c}\mathrm{R}^{2} \\
\text { Chang } \\
\mathrm{e}\end{array}$ & $\begin{array}{c}\mathrm{F} \\
\text { change }\end{array}$ & $\mathrm{df1}$ & $\mathrm{df2}$ & $\begin{array}{l}\text { Sig. } \\
\mathrm{F} \\
\text { Change }\end{array}$ \\
\hline 0.826 & 0.683 & 0.681 & 0.73020 & 1.765 & 0.683 & 544.016 & 1 & 253 & 0.000 \\
\hline
\end{tabular}

Source: Output of SPSS_18

Simple linear regression was used as the statistical tool to examine the relationship between ER (independent variable) and BP (dependent variable). Table 3 highlights the regression model-1 which shows all the requite results. The coefficient of correlation is 0.826 which shows a very high degree of correlation between ER and BP. The adjusted R square value was 0.681 which indicates that $68 \%$ variations in BP can be predicted from ER and rest of the variations are unexplained. The value of durbin Watson shows positive auto correlation between ER and BP.

Table 4: Multiple Regression Analysis

\begin{tabular}{|c|c|c|c|c|l|}
\hline Model:1 & \multicolumn{1}{|}{$\begin{array}{c}\text { Unstandardized } \\
\text { coefficients }\end{array}$} & $\begin{array}{c}\text { Standardized } \\
\text { coefficients }\end{array}$ & Sig. & \\
\cline { 2 - 5 } & B & Std Error & Beta & & 0.000 \\
\hline Constant & 0.537 & 0.148 & & 23.324 & 0.000 \\
\hline $\begin{array}{c}\text { Economic } \\
\text { Responsibilities }\end{array}$ & 0.841 & 0.036 & 0.826 & & \\
\hline ANOVA F Value=544.016** [Significant at 5\%] & & & \\
\hline \multicolumn{7}{|c|}{ Dependent Variable: Brand Positioning } \\
\hline
\end{tabular}

Source: Output of SPSS_18

The values of beta coefficients and ANOVA are shown in Table 4. ANOVA shows that the overall model is significant because the $F$ value is 544.016 which is significant at $95 \%$ confidence level. Furthermore, the unstandardized beta value shows the impact of the predictor variable (ER) on the dependent variable (BP). The beta coefficients are positive and significant. It suggests that for one unit increase in ER, there will be 0.841 unit increase in BP. Finally, the null hypothesis is rejected because $\mathrm{P}<0.05$ and it can be said that economic responsibilities has a significant impact on brand positioning. 
INTERNATIONAL JOURNAL OF ACADEMIC RESEARCH IN ACCOUNTING, FINANCE AND MANAGEMENT SCIENCES

Vol. 11, No. 1, 2021, E-ISSN: 2225-8329 @ 2021 HRMARS

$H_{01.2}$ : There is no significant impact of legal responsibilities (LR) on brand positioning (BP). $H_{a 1.2}$ : There is a significant impact of legal responsibilities (LR) on brand positioning (BP).

Table 5: Regression [Legal responsibilities \& Brand positioning]

\begin{tabular}{|c|c|c|c|c|c|c|c|c|l|}
\hline \multicolumn{9}{|c|}{ Model-2 } & \multicolumn{5}{c|}{ Change Statistics } \\
\hline$R$ & $\mathbf{R}^{\mathbf{2}}$ & $\begin{array}{c}\text { Adjusted } \\
\mathbf{R}^{\mathbf{2}}\end{array}$ & $\begin{array}{c}\text { Standar } \\
\mathrm{d} \text { Error }\end{array}$ & $\begin{array}{c}\text { Durbin } \\
\text { Watson }\end{array}$ & $\begin{array}{c}\mathrm{R}^{2} \\
\text { Change }\end{array}$ & $\begin{array}{c}\mathrm{F} \\
\text { change }\end{array}$ & $\mathrm{df1}$ & $\mathrm{df2}$ & $\begin{array}{l}\text { Sig. } \\
\text { F Change }\end{array}$ \\
\hline 0.728 & 0.530 & 0.528 & 0.92101 & 1.818 & 0.530 & $\begin{array}{l}284.73 \\
8\end{array}$ & 1 & 253 & 0.000 \\
\hline
\end{tabular}

Source: Output of SPSS_18

Simple linear regression was used as the statistical tool to examine the relationship between ER (independent variable) and BP (dependent variable). Table 5 highlights the regression model-2 which shows all the requite results. The coefficient of correlation is 0.728 which shows a high degree of correlation between LR and BP. The adjusted $R$ square value was 0.528 which indicates that $52.8 \%$ variations in BP can be predicted from LR and rest of the variations were unexplained. The value of durbin Watson shows positive auto correlation between LR and BP.

Table 6: Multiple Regression Analysis

\begin{tabular}{|c|c|c|c|c|l|}
\hline Model:2 & $\begin{array}{c}\text { Unstandardized } \\
\text { coefficients }\end{array}$ & $\begin{array}{c}\text { Standardized } \\
\text { coefficients }\end{array}$ & \multirow{2}{*}{ Sig. } \\
\cline { 2 - 5 } & B & Std Error & Beta & & \\
\hline Constant & 0.706 & 0.186 & & 16.789 & 0.000 \\
\hline $\begin{array}{c}\text { Legal } \\
\text { Responsibilities }\end{array}$ & 0.767 & 0.045 & 0.728 & 0.000 \\
\hline ANOVA F Value=284.738** Dependent Variable: Brand Positioning \\
\hline \multicolumn{7}{|c|}{ [Significant at 5\%] } \\
\hline
\end{tabular}

Source: Output of SPSS_18

The values of beta coefficients and ANOVA are shown in Table 6. ANOVA shows that the overall model is significant because the $F$ value is significant at $95 \%$ confidence level. Furthermore, the unstandardized beta value shows the impact of the predictor variable (LR) on the dependent variable (BP). The beta coefficients are positive and significant. It suggests that for one unit increase in LR, there will be 0.767 unit increase in BP. Finally, the null hypothesis is rejected because $\mathrm{P}<0.05$ and it can be said that legal responsibilities has a significant impact on brand positioning.

$H_{01.3:}$ There is no significant impact of ethical responsibilities on brand positioning (BP).

$H_{a 1.3}$ : There is a significant impact of ethical responsibilities on brand positioning (BP). 
INTERNATIONAL JOURNAL OF ACADEMIC RESEARCH IN ACCOUNTING, FINANCE AND MANAGEMENT SCIENCES

Vol. 11, No. 1, 2021, E-ISSN: 2225-8329 @ 2021 HRMARS

Table 7: Regression [Ethical responsibilities \& Brand Positioning]

\begin{tabular}{|c|c|c|c|c|c|c|c|c|c|}
\hline \multicolumn{3}{|c|}{ Model-3 } & \multicolumn{5}{c|}{ Change Statistics } \\
\hline$R$ & $\mathbf{R}^{\mathbf{2}}$ & $\begin{array}{c}\text { Adjusted } \\
\mathbf{R}^{\mathbf{2}}\end{array}$ & $\begin{array}{c}\text { Standar } \\
\mathrm{d} \text { Error }\end{array}$ & $\begin{array}{c}\text { Durbin } \\
\text { Watson }\end{array}$ & $\begin{array}{c}\mathrm{R}^{2} \\
\text { Change }\end{array}$ & $\begin{array}{c}\mathrm{F} \\
\text { change }\end{array}$ & $\mathrm{df1}$ & $\mathrm{df2}$ & $\begin{array}{l}\text { Sig. } \\
\mathrm{F} \\
\text { Change }\end{array}$ \\
\hline 0.555 & 0.309 & 0.306 & 1.14497 & 1.597 & 0.309 & $\begin{array}{l}112.89 \\
6\end{array}$ & 1 & 253 & 0.000 \\
\hline
\end{tabular}

Source: Output of SPSS_18

Table 7 highlights the regression model-3 which shows all the requite results. The coefficient of correlation is 0.555 which shows a moderate degree of correlation between them. The adjusted $\mathrm{R}$ square value was 0.306 which indicates that only $30 \%$ variations in BP can be predicted from ethical responsibilities and rest of the variations were unexplained. The value of durbin Watson shows positive auto correlation between them.

Table 8: Multiple Regression Analysis

\begin{tabular}{|c|c|c|c|c|c|}
\hline \multirow[t]{2}{*}{ Model:3 } & \multicolumn{2}{|c|}{$\begin{array}{l}\text { Unstandardized } \\
\text { coefficients }\end{array}$} & \multirow{2}{*}{$\begin{array}{c}\text { Standardized } \\
\text { coefficients } \\
\text { Beta } \\
\end{array}$} & \multirow[t]{2}{*}{$\mathrm{t}$} & \multirow[t]{2}{*}{ Sig. } \\
\hline & B & Std Error & & & \\
\hline Constant & 1.378 & 0.232 & & 5.953 & 0.000 \\
\hline $\begin{array}{c}\text { Ethical } \\
\text { Responsibilities }\end{array}$ & 0.601 & 0.057 & 0.555 & 10.625 & 0.000 \\
\hline \multicolumn{6}{|c|}{ ANOVA F Value $=112.896 * * \quad$ [Significant at $5 \%]$} \\
\hline \multicolumn{6}{|c|}{ Dependent Variable: Brand Positioning } \\
\hline
\end{tabular}

Source: Output of SPSS_18

The values of beta coefficients and ANOVA are shown in Table 8. ANOVA shows that the overall model is significant because the $F$ value is significant at $95 \%$ confidence level. Furthermore, the unstandardized beta coefficients are positive and significant. Finally, the null hypothesis is rejected because $\mathrm{P}<0.05$ and it can be said that ethical responsibilities has a significant impact on brand positioning.

H01.4: There is no significant impact of philanthropic responsibilities (PR) on brand positioning (BP). $H_{a 1.4:}$ There is a significant impact of philanthropic responsibilities (PR) on brand positioning (BP).

Table 9: Regression [Philanthropic responsibilities \& Brand Positioning]

\begin{tabular}{|c|c|c|c|c|c|c|c|c|l|}
\hline \multicolumn{9}{|c|}{ Model-4 } & \multicolumn{5}{c|}{ Change Statistics } \\
\hline$R$ & $\mathbf{R}^{\mathbf{2}}$ & $\begin{array}{c}\text { Adjusted } \\
\mathbf{R}^{\mathbf{2}}\end{array}$ & $\begin{array}{c}\text { Standar } \\
\mathrm{d} \text { Error }\end{array}$ & $\begin{array}{c}\text { Durbin } \\
\text { Watson }\end{array}$ & $\begin{array}{c}\mathrm{R}^{2} \\
\text { Chang } \\
\mathrm{e}\end{array}$ & $\begin{array}{c}\mathrm{F} \\
\text { change }\end{array}$ & $\mathrm{df1}$ & $\mathrm{df2}$ & $\begin{array}{l}\text { Sig. } \\
\mathrm{F} \\
\text { Change }\end{array}$ \\
\hline
\end{tabular}


INTERNATIONAL JOURNAL OF ACADEMIC RESEARCH IN ACCOUNTING, FINANCE AND MANAGEMENT SCIENCES

Vol. 11, No. 1, 2021, E-ISSN: 2225-8329 @ 2021 HRMARS

\begin{tabular}{|l|l|l|l|l|l|l|l|l|l|}
\hline 0.666 & 0.443 & 0.441 & 1.03195 & 1.835 & 0.443 & 201.592 & 1 & 253 & 0.000 \\
\hline
\end{tabular}

Source: Output of SPSS_18

Simple linear regression was used as the statistical tool to examine the relationship between PR (independent variable) and BP (dependent variable). Table 9 highlights the regression model-4 which shows all the requite results. The coefficient of correlation is 0.666 which shows a moderate degree of correlation between PR and BP. The adjusted R square value was 0.441 which indicates that $44 \%$ variations in BP can be predicted from PR and rest of the variations were unexplained. The value of durbin Watson shows positive auto correlation between PR and BP.

Table 10: Multiple Regression Analysis

\begin{tabular}{|c|c|c|c|c|l|}
\hline Model:4 & \multicolumn{2}{|l|}{$\begin{array}{c}\text { Unstandardized } \\
\text { coefficients }\end{array}$} & $\begin{array}{c}\text { Standardized } \\
\text { coefficients }\end{array}$ & \multirow{2}{*}{ Sig. } \\
\cline { 2 - 4 } & B & Std Error & Beta & & \\
\hline Constant & 0.802 & 0.209 & & 3.844 & 0.000 \\
\hline $\begin{array}{c}\text { Philanthropic } \\
\text { Responsibilities }\end{array}$ & 0.723 & 0.051 & 0.666 & 14.198 & 0.000 \\
\hline ANOVA F Value=201.592** [Significant at 5\%] \\
\hline \multicolumn{7}{|c|}{ Dependent Variable: Brand Positioning } \\
\hline
\end{tabular}

Source: Output of SPSS_18

The values of beta coefficients and ANOVA are shown in Table 10. ANOVA shows that the overall model is significant because the $F$ value is significant at $95 \%$ confidence level. Furthermore, the unstandardized beta value shows the impact of the predictor variable (PR) on the dependent variable (BP). The beta coefficients are positive and significant. It suggests that for one unit increase in PR, there will be 0.723 unit increase in BP. Finally, the null hypothesis is rejected because $\mathrm{P}<0.05$ and it can be said that philanthropic responsibilities has a significant impact on brand positioning.

$\mathbf{H}_{\text {02.1 }}$ : There is no significant impact of economic responsibilities (ER) on brand loyalty (BL). $\mathbf{H}_{\mathrm{a} 2.1}$ : There is a significant impact of economic responsibilities (ER) on brand loyalty (BL).

Table 11: Regression [Economic responsibilities \& Brand loyalty]

\begin{tabular}{|c|c|c|c|c|c|c|c|c|c|}
\hline \multicolumn{9}{|c|}{ Model-5 } & \multicolumn{5}{c|}{ Change Statistics } \\
\hline$R$ & $\mathbf{R}^{\mathbf{2}}$ & $\begin{array}{c}\text { Adjusted } \\
\mathbf{R}^{\mathbf{2}}\end{array}$ & $\begin{array}{c}\text { Standar } \\
\mathrm{d} \text { Error }\end{array}$ & $\begin{array}{c}\text { Durbin } \\
\text { Watson }\end{array}$ & $\begin{array}{c}\mathrm{R}^{2} \\
\text { Change }\end{array}$ & $\begin{array}{c}\mathrm{F} \\
\text { change }\end{array}$ & $\mathrm{df1}$ & $\mathrm{df2}$ & $\begin{array}{l}\text { Sig. } \\
\mathrm{F} \\
\text { Change }\end{array}$ \\
\hline 0.941 & 0.885 & 0.885 & 0.21169 & 1.903 & 0.885 & 1955.93 & 1 & 253 & 0.000 \\
\hline
\end{tabular}

Source: Output of SPSS_18

Simple linear regression was used as the statistical tool to examine the relationship between ER (independent variable) and BL (dependent variable). Table 11 highlights the regression model-5 
INTERNATIONAL JOURNAL OF ACADEMIC RESEARCH IN ACCOUNTING, FINANCE AND MANAGEMENT SCIENCES

Vol. 11, No. 1, 2021, E-ISSN: 2225-8329 @ 2021 HRMARS

which shows all the requite results. The coefficient of correlation is 0.941 which shows a high degree of correlation between ER and BL. The adjusted R square value was 0.885 which indicates that $88 \%$ variations in $B L$ can be predicted from $E R$ and rest of the variations are unexplained. The value of durbin Watson shows positive auto correlation between ER and BL.

Table 12: Multiple Regression Analysis

\begin{tabular}{|c|c|c|c|c|l|}
\hline \multirow{2}{*}{ Model:5 } & $\begin{array}{c}\text { Unstandardized } \\
\text { coefficients }\end{array}$ & $\begin{array}{c}\text { Standardized } \\
\text { coefficients }\end{array}$ & \multirow{2}{*}{ Sig. } \\
\cline { 2 - 4 } & B & Std Error & Beta & \\
\hline Constant & 0.552 & 0.064 & & 8.684 & 0.000 \\
\hline $\begin{array}{c}\text { Economic } \\
\text { Responsibilities }\end{array}$ & 0.719 & 0.016 & 0.941 & 44.226 & 0.000 \\
\hline ANOVA F Value=1955.933** & [Significant at 5\%] \\
\hline \multicolumn{7}{|c|}{ Dependent Variable: Brand Loyalty } \\
\hline
\end{tabular}

Source: Output of SPSS_18

The values of beta coefficients and ANOVA are shown in Table 12. ANOVA shows that the overall model is significant because the $F$ value is 1955.533 which is significant at $95 \%$ confidence level. Furthermore, the unstandardized beta value shows the impact of the predictor variable (ER) on the dependent variable $(\mathrm{BL})$. The beta coefficients are positive and significant. It suggests that for one unit increase in ER, there will be 0.719 unit increase in BL. Finally, the null hypothesis is rejected because $\mathrm{P}<0.05$ and it can be said that economic responsibilities has a significant impact on brand loyalty.

$\mathbf{H}_{\text {02.2: }}$ : There is no significant impact of legal responsibilities (LR) on brand loyalty (BL).

$\mathbf{H}_{\mathrm{a2.2}}$ : There is a significant impact of legal responsibilities (LR) on brand loyalty (BL).

Table 13: Regression [Legal responsibilities \& Brand loyalty]

\begin{tabular}{|c|c|c|c|c|c|c|c|c|l|}
\hline \multicolumn{9}{|c|}{ Model-6 } & \multicolumn{5}{c|}{ Change Statistics } \\
\hline$R$ & $\mathbf{R}^{\mathbf{2}}$ & $\begin{array}{c}\text { Adjusted } \\
\mathbf{R}^{\mathbf{2}}\end{array}$ & $\begin{array}{c}\text { Standar } \\
\mathrm{d} \text { Error }\end{array}$ & $\begin{array}{c}\text { Durbin } \\
\text { Watson }\end{array}$ & $\begin{array}{c}\mathrm{R}^{2} \\
\text { Change }\end{array}$ & $\begin{array}{c}\mathrm{F} \\
\text { change }\end{array}$ & df1 & df2 & $\begin{array}{l}\text { Sig. } \\
\text { F Change }\end{array}$ \\
\hline 0.733 & 0.537 & 0.535 & 0.55076 & 1.789 & 0.537 & 292.933 & 1 & 253 & 0.000 \\
\hline
\end{tabular}

Source: Output of SPSS_18

Table 13 highlights the regression model- 6 which shows all the requite results. The coefficient of correlation is 0.733 which shows a moderate degree of correlation between LR and BL. The adjusted $R$ square value was 0.535 which indicates that $53 \%$ variations in $B L$ can be predicted from $L R$ and rest of the variations are unexplained. The value of durbin Watson shows positive auto correlation between LR and BL. 
Table 14: Multiple Regression Analysis

\begin{tabular}{|c|c|c|c|c|l|}
\hline Model:6 & \multicolumn{1}{|}{$\begin{array}{c}\text { Unstandardized } \\
\text { coefficients }\end{array}$} & $\begin{array}{c}\text { Standardized } \\
\text { coefficients }\end{array}$ & Sig. \\
\cline { 2 - 4 } & B & Std Error & Beta & & \\
\hline Constant & 1.436 & 0.125 & & 11.524 & 0.000 \\
\hline $\begin{array}{c}\text { Legal } \\
\text { Responsibilities }\end{array}$ & 0.564 & 0.033 & 0.733 & 17.115 & 0.000 \\
\hline ANOVA F Value=292.933** & [Significant at 5\%] & \\
\hline \multicolumn{7}{|c|}{ Dependent Variable: Brand Loyalty } \\
\hline
\end{tabular}

Source: Output of SPSS_18

The values of beta coefficients and ANOVA are shown in Table 14. ANOVA shows that the overall model is significant because the $F$ value is 292.933 which is significant at $95 \%$ confidence level. Furthermore, the unstandardized beta value shows the impact of the predictor variable (LR) on the dependent variable (BL). The beta coefficients are positive and significant. It suggests that for one unit increase in LR, there will be 0.564 unit increase in BL. Finally, the null hypothesis is rejected because $\mathrm{P}<0.05$ and it can be said that there is a significant impact of legal responsibilities on brand loyalty.

$H_{02.3:}$ There is no significant impact of ethical responsibilities on brand loyalty (BL).

$H_{a 2.3}$ : There is a significant impact of ethical responsibilities on brand loyalty (BL).

Table 15: Regression [Ethical responsibilities \& Brand Loyalty]

\begin{tabular}{|c|c|c|c|c|c|c|c|c|c|}
\hline \multicolumn{9}{|c|}{ Model-7 } & \multicolumn{5}{c|}{ Change Statistics } \\
\hline$R$ & $\mathbf{R}^{\mathbf{2}}$ & $\begin{array}{c}\text { Adjusted } \\
\mathbf{R}^{\mathbf{2}}\end{array}$ & $\begin{array}{c}\text { Standard } \\
\text { Error }\end{array}$ & $\begin{array}{c}\text { Durbin } \\
\text { Watson }\end{array}$ & $\begin{array}{c}\mathrm{R}^{2} \\
\text { Change }\end{array}$ & $\begin{array}{c}\mathrm{F} \\
\text { change }\end{array}$ & df1 & df2 & $\begin{array}{l}\text { Sig. } \\
\mathrm{F} \\
\text { Change }\end{array}$ \\
\hline 0.855 & 0.731 & 0.730 & 0.28184 & 1.869 & 0.731 & $\begin{array}{l}688.59 \\
5\end{array}$ & 1 & 253 & 0.000 \\
\hline
\end{tabular}

Source: Output of SPSS_18

Table 15 highlights the regression model-7 which shows all the requite results. The coefficient of correlation is 0.855 which shows a high degree of correlation between them. The adjusted $\mathrm{R}$ square value was 0.730 which indicates that only $73 \%$ variations in $\mathrm{BL}$ can be predicted from ethical responsibilities and rest of the variations were unexplained. The value of durbin Watson shows positive auto correlation between them. 
Table 16: Multiple Regression Analysis

\begin{tabular}{|c|c|c|c|c|l|}
\hline Model:7 & $\begin{array}{c}\text { Unstandardized } \\
\text { coefficients }\end{array}$ & $\begin{array}{c}\text { Standardized } \\
\text { coefficients }\end{array}$ & \multirow{2}{*}{ Sig. } \\
\cline { 2 - 4 } & B & Std Error & Beta & \\
\hline Constant & 1.629 & 0.064 & & 25.539 & 0.000 \\
\hline $\begin{array}{c}\text { Ethical } \\
\text { Responsibilities }\end{array}$ & 0.443 & 0.017 & 0.855 & 26.241 & 0.000 \\
\hline ANOVA F Value=688.595** & [Significant at 5\%] & \\
\hline \multicolumn{7}{|c|}{ Dependent Variable: Brand Loyalty } \\
\hline
\end{tabular}

Source: Output of SPSS_18

The values of beta coefficients and ANOVA are shown in Table 16. ANOVA shows that the overall model is significant because the $F$ value is significant at $95 \%$ confidence level. Furthermore, the unstandardized beta coefficients are positive and significant. Finally, the null hypothesis is rejected because $\mathrm{P}<0.05$ and it can be said that there is a significant impact of ethical responsibilities on brand loyalty.

H02.4: There is no significant impact of philanthropic responsibilities (PR) on brand loyalty (BL). $H_{a 2.4}$ : There is a significant impact of philanthropic responsibilities (PR) on brand loyalty (BL).

Table 17: Regression [Philanthropic responsibilities \& Brand Loyalty]

\begin{tabular}{|c|c|c|c|c|c|c|c|c|c|}
\hline \multicolumn{9}{|c|}{ Model-8 } & \multicolumn{5}{c|}{ Change Statistics } \\
\hline$R$ & $\mathbf{R}^{\mathbf{2}}$ & $\begin{array}{c}\text { Adjusted } \\
\mathbf{R}^{\mathbf{2}}\end{array}$ & $\begin{array}{c}\text { Standar } \\
\mathrm{d} \text { Error }\end{array}$ & $\begin{array}{c}\text { Durbin } \\
\text { Watson }\end{array}$ & $\begin{array}{c}\mathrm{R}^{2} \\
\text { Change }\end{array}$ & $\begin{array}{c}\mathrm{F} \\
\text { change }\end{array}$ & $\mathrm{df1}$ & $\mathrm{df2}$ & $\begin{array}{l}\text { Sig. } \\
\mathrm{F} \\
\text { Change }\end{array}$ \\
\hline 0.724 & 0.524 & 0.522 & 0.41887 & 1.958 & 0.524 & 278.288 & 1 & 253 & 0.000 \\
\hline
\end{tabular}

Source: Output of SPSS_18

Simple linear regression was used as the statistical tool to examine the relationship between PR (independent variable) and $\mathrm{BL}$ (dependent variable). Table 17 highlights the regression model-4 which shows all the requite results. The coefficient of correlation is 0.724 which shows a moderate degree of correlation between PR and BL. The adjusted $R$ square value was 0.522 which indicates that $52 \%$ variations in $B L$ can be predicted from PR and rest of the variations were unexplained. The value of durbin Watson shows positive auto correlation between PR and BL. 
Table 18: Multiple Regression Analysis

\begin{tabular}{|c|c|c|c|c|l|}
\hline Model:8 & \multicolumn{1}{|}{$\begin{array}{c}\text { Unstandardized } \\
\text { coefficients }\end{array}$} & $\begin{array}{c}\text { Standardized } \\
\text { coefficients }\end{array}$ & Sig. \\
\cline { 2 - 4 } & B & Std Error & Beta & & \\
\hline Constant & 1.677 & 0.095 & & 17.695 & 0.000 \\
\hline $\begin{array}{c}\text { Philanthropic } \\
\text { Responsibilities }\end{array}$ & 0.418 & 0.025 & 0.724 & 16.682 & 0.000 \\
\hline ANOVA F Value=278.288** Dependent Variable: Brand Loyalty \\
\hline \multicolumn{7}{|c|}{ [Significant at 5\%] } \\
\hline
\end{tabular}

Source: Output of SPSS_18

The values of beta coefficients and ANOVA are shown in Table 18. ANOVA shows that the overall model is significant because the $F$ value is significant at $95 \%$ confidence level. Furthermore, the unstandardized beta value shows the impact of the predictor variable (PR) on the dependent variable (BL). The beta coefficients are positive and significant. It suggests that for one unit increase in PR, there will be 0.418 unit increase in BL. Finally, the null hypothesis is rejected because $\mathrm{P}<0.05$ and it can be said that there is a significant impact of philanthropic responsibilities on brand loyalty.

Table 19: Hypotheses Tested in abridged form

\begin{tabular}{|l|l|l|}
\hline & HYPOTHESES & Results \\
\hline Ho1 & There is no significant impact of CSR on brand positioning (BP). & \\
\hline $\mathrm{H}_{01.1}$ & There is no significant impact of economic responsibilities on BP. & Rejected \\
\hline $\mathrm{H}_{01.2}$ & There is no significant impact of legal responsibilities on BP. & Rejected \\
\hline $\mathrm{H}_{01.3}$ & There is no significant impact of ethical responsibilities on BP. & Rejected \\
\hline $\mathrm{H}_{01.4}$ & There is no significant impact of philanthropic responsibilities on BP. & Rejected \\
\hline $\mathrm{H}_{02}$ & There is no significant impact of CSR on Brand Loyalty (BL). & \\
\hline $\mathrm{H}_{02.1}$ & There is no significant impact of economic responsibilities on BL. & Rejected \\
\hline $\mathrm{H}_{02.2}$ & There is no significant impact of legal responsibilities on BL. & Rejected \\
\hline $\mathrm{H}_{02.3}$ & There is no significant impact of ethical responsibilities on BL. & Rejected \\
\hline $\mathrm{H}_{02.4}$ & There is no significant impact of philanthropic responsibilities on BL. & Rejected \\
\hline
\end{tabular}

Source: Based on the preceding results

\section{Concluding Remarks}

The first decade of the $21^{\text {st }}$ century witnessed a swing away from charity and traditional philanthropy towards more direct engagement of business in mainstream development and concern for disadvantaged groups in the society. This has resulted into the concept of Corporate Social Responsibility (CSR). It states that firms must integrate social and environmental concerns in their business activities voluntarily. This research was conducted to examine the impact of CSR on brand 
positioning and brand loyalty in Jordan. A structured questionnaire was used for collecting primary data. A judgemental sampling was adopted for the selection of 255 respondents from selected FMCGs in Jordan. Before hypotheses testing, reliability of all statements was tested with the application of cronbach alpha. The values of all components were good which paved the way for testing hypotheses. Two main hypotheses were developed in the study. The first hypothesis tests the relationship between CSR and brand positioning whereas second hypothesis tests the relationship between CSR and brand loyalty. All these were tested with the application of simple linear regression. The findings highlighted that regression coefficients of all study variables were positive and statistically significant at $95 \%$ confidence level. Finally, the research proved that there is a significant impact of CSR on brand positioning and brand loyalty. These findings were in line with previous empirical studies Battaglia, et al (2014); Dapi and Phiri, (2015); Nagalatha (2015), Lin, (2016); Bediako, (2017); Lu, et al., (2020).

\section{Empirical Contribution}

This study contributes to the research of CSR because few studies were conducted to examine the impact of CSR's dimensions effect on brand positioning and brand loyalty in FMCG sector of Jordan. The contribution of the study has been to understand the attitudes of customers' and their beliefs regarding those firms who are obliging CSR activities. The results of this study will help all the FMCG firms to develop an ideal CSR model for their long term success and survival strategy. Furthermore, the tremendous contribution of this research is that those companies which were not fulfilling CSR earlier will start doing it. They will try to minimize social costs and maximize social benefits by charging fair prices for their products, paying fair salaries to their staff, not using child labour, paying regular taxes to government, doing proper solid waste management, buying raw materials from ethical sources. All these CSR activities will benefit to all sections of the society and thus leads to sustainable development in Jordan.

\section{Limitations and Further Research}

This study was based on data collected by 255 respondents through field survey. Structured questionnaires were used to collect the responses and reviews of respondents during the second half of 2019. The negligence on the part of respondents' might create variation in results. Therefore, future researches should be conducted with large sample size. In addition to, Carlos 1991 model was used to develop components of CSR. All the four components were measured by limited statements in the questionnaire and therefore in the future, more statements should be used which would increase the accuracy of the dimensions. Furthermore, FMCG companies were included in the study. For future researches, some more companies of another industry should be included or a comparison between different industries should be made to enhance the generalizability of the derived results.

\section{References}

Abushttal, M. M., and Al Serhan, A. F. (2020). Impact of brand image on brand equity with special reference to consumer durables. The International Journal of Humanities \& Social Studies, Vol. 8 Issue 11, 345-353. DOI: 10.24940/theijhss/2020/v8/i11/HS2011-081 
INTERNATIONAL JOURNAL OF ACADEMIC RESEARCH IN ACCOUNTING, FINANCE AND

MANAGEMENT SCIENCES

Vol. 11, No. 1, 2021, E-ISSN: 2225-8329 @ 2021 HRMARS

Arevalo, J. A., and Aravind, D. (2011). Corporate social responsibility practices in India: approach, drivers, and barriers. Corporate Governance, Vol. 11 No. 4, 399-414. URL: https://doi.org/10.1108/14720701111159244

Aras, G., Aybars, A., and Kutlu, O. (2010). Managing corporate performance: Investigating the relationship between corporate social responsibility and financial performance in emerging markets. International Journal of Productivity and Performance Management, Vol. 59 No. 3, 229-254. URL: https://doi.org/10.1108/17410401011023573

Bediako, B. O. (2017). The Impact of Corporate Social Responsibility on Customer Loyalty. A Case Study of StanBed Tours ky. University of Applied Sciences, International Business.

Carroll, A.B. Carroll's pyramid of CSR: taking another look. Int J Corporate Soc Responsibility 1, 3 (2016). https://doi.org/10.1186/s40991-016-0004-6

Dapi, B., and Phiri, M. A. P. (2015). The impact of corporate social responsibility on brand loyalty. Journal of Governance and Regulation, Vol. 4, Issue 4, 8-16.

Galbreath, J. (2010). How does corporate social responsibility benefit firms? Evidence from Australia. European Business Review, Vol. 22, No. 4, 411-431. DOI:10.1108/ 09555341011056186

Gudjonsdottir, E., and Jusubova, A. (2015). CSR's effect on brand image. International business and marketing program. Bachelor Thesis, Kristianstad University. URL: http://www.divaportal.org/smash/get/diva2:867885/FULLTEXT01.pdf

Lin, S. M. (2016). Understanding corporate social responsibility and brand equity: an investigation of restaurant brand attributes and customer traits. Master Thesis, Oklahoma State University.

Nagalatha, A. S. (2015). Perception of managers on corporate social responsibility. Doctoral Thesis, Department of Commerce, University of Madras, Chennai, India.

Oberseder, M., Schlegelmilch, B. B., \& Murphy, P. E. (2013). CSR practice and consumer perceptions. Journal of Business Research, 66(10), 1839-1851.URL: http://hdl.handle.net/10.1007/s00187014-0198-2

Park, E., Kim, K. J., \& Kwon, S. J. (2017). Corporate Social Responsibility as a Determinant of Consumer Loyalty: An Examination of Ethical Standard, Satisfaction, and Trust. Journal of Business Research, 76, 8-13. https:// doi.org/ 10.1016/ j.jbusres.2017.02.017

Peloza, J., \& Shang, J. (2011) How can corporate social responsibility activities create value for stakeholders? A systematic review. Journal of the Academy of Marketing Science, 39, 117-35. doi: 10.1007/s11747-010-0213-6

Russo, A., \& Perrini, F. (2010). Investigating stakeholder theory and social capital: CSR in large firms and SMEs. Journal of Business Ethics, 91, 207-21. doi: 10.1007/s10551-009-0079-z

Sen, S., Bhattacharya, C. B., \& Korschun, D. (2006). The role of corporate social responsibility in strengthening multiple stakeholder relationship: A field experiment. Journal of the Academy of Marketing Science, 34(2), 158-166. http:// dx.doi.org/ 10.1177/0092070305284978

Wu, S. I., \& Wang, W. H. (2014). Impact of CSR Perception on Brand Image, Brand Attitude, and Buying Willingness: A Study of a Global Café. International Journal of Marketing Studies, 6 (6), 43-56. https://doi.org/10.5539/ijms.v6n6p43

Ying, F. (2005).Ethical branding and corporate reputation. Corporate Communication: An International Marketing Journal, Vol. 10, (4), 341-350. 


\section{APPENDIX}

Questionnaire

Demographic Profile

Name (Optional):-

\section{Gender.}

Age:

Education:

Monthly Income:

Marital Status.

(Tick $(V)$ the appropriate box 1=strongly Disagree, 2=Disagree, 3= neither Agree nor Disagree, 4=Agree and 5=strongly Agree

\begin{tabular}{|c|c|c|c|c|c|c|}
\hline \multicolumn{2}{|c|}{ Economic Responsibilities } & 1 & 2 & 3 & 4 & 5 \\
\hline 1 & $\begin{array}{l}\text { This company also aims to maximise profits obtained from } \\
\text { its CSR activities. }\end{array}$ & & & & & \\
\hline 2 & This company creates employment opportunities. & & & & & \\
\hline 3 & The company does sustainable development. & & & & & \\
\hline \multicolumn{7}{|c|}{ Legal Responsibilities } \\
\hline 5 & $\begin{array}{l}\text { The company always pays its taxes regularly without any } \\
\text { delay. }\end{array}$ & & & & & \\
\hline 6 & $\begin{array}{l}\text { This company abides by the norms for legitimate } \\
\text { functioning of CSR activities. }\end{array}$ & & & & & \\
\hline 7 & $\begin{array}{l}\text { I find this company trustworthy as it provides fully } \\
\text { accurate information about its products to the customers. }\end{array}$ & & & & & \\
\hline \multicolumn{7}{|c|}{ Ethical Responsibilities } \\
\hline 8 & $\begin{array}{l}\text { The managerial decisions related with the employees are } \\
\text { usually fair. }\end{array}$ & & & & & \\
\hline 9 & $\begin{array}{l}\text { This company behaves ethically and honestly with its } \\
\text { customers. }\end{array}$ & & & & & \\
\hline 10 & This company avoids unfair competition. & & & & & \\
\hline 11 & $\begin{array}{l}\text { The company policies are flexible and provide room for } \\
\text { maintain work-life balance to employees. }\end{array}$ & & & & & \\
\hline \multicolumn{7}{|c|}{ Philanthropic Responsibilities } \\
\hline 13 & $\begin{array}{l}\text { This company reserves a portion of its profits for donations } \\
\text { and social work. }\end{array}$ & & & & & \\
\hline
\end{tabular}


INTERNATIONAL JOURNAL OF ACADEMIC RESEARCH IN ACCOUNTING, FINANCE AND MANAGEMENT SCIENCES

Vol. 11, No. 1, 2021, E-ISSN: 2225-8329 @ 2021 HRMARS

\begin{tabular}{|l|l|l|l|l|l|}
\hline $\mathbf{1 4}$ & $\begin{array}{l}\text { This company integrates charitable contribution into it } \\
\text { business activities }\end{array}$ & & & & \\
\hline $\mathbf{1 5}$ & $\begin{array}{l}\text { This company considers itself responsible to benefit the } \\
\text { community in its operating areas as a reimbursement. }\end{array}$ & & & \\
\hline Brand Positioning & & & & \\
\hline $\mathbf{1 6}$ & The likely quality of this brand is extremely high. & & & \\
\hline $\mathbf{1 7}$ & $\begin{array}{l}\text { The high quality products of the company help me in } \\
\text { remembering it. }\end{array}$ & & & & \\
\hline $\mathbf{1 8}$ & $\begin{array}{l}\text { I do not feel any difficulty in thinking and picturise this } \\
\text { company. }\end{array}$ & & & & \\
\hline $\mathbf{B r a n d}$ Loyalty & $\begin{array}{l}\text { I will restain from buying any other products if this brand's } \\
\text { products are available at the store. }\end{array}$ & & & & \\
\hline $\mathbf{1 9}$ & $\begin{array}{l}\text { I would prefer to buy this brand even if another brand has } \\
\text { same feature. }\end{array}$ & & & & \\
\hline $\mathbf{2 1}$ & I will remain faithful to this company. & & & & \\
\hline
\end{tabular}

